\title{
TWO TRANSPARENT BERYL VARIETIES FROM THE KAATIALA PEGMATITE, FINLAND
}

\author{
Olavi Erämetsä, Kalervo Nieminen and Lauri Niinistö
}

\begin{abstract}
Erämetsä, Olavi; Nieminen, Kalervo and Ninistö, Lauri 1973: Two transparent beryl varieties from the Kaatiala pegmatite, Finland. Bull. Geol. Soc. Finland 45, 125-130.

Abstract

Chemical and crystallographic data are given for two transparent beryls and, in comparison, for a normal nontransparent specimen from the Kaatiala pegmatite. The chemical analyses include the determinations of the main components, alkalis, water and 21 trace elements.

Olavi Erämetsä, Kalervo Nieminen and Lauri Niinistö, Department of Chemistry, Helsinki University of Tecbnology, SF-02150 Otaniemi, Finland.
\end{abstract}

\section{Introduction}

The pegmatite of Kaatiala is located in the parish of Kuortane, approximately 100 miles southeast of the town of Vaasa. The pegmatite is a lens-shaped unit which dips gently to the $\mathrm{NE}$ and cuts nearly perpendicularly across the lineation of the granodiorite country rock. The pegmatite is well zoned with several quartz cores. The cores are to be found mainly in the outer part of the intermediate zone which consists of huge potash feldspar crystals and is situated in the central part of the deposit. A Na-Li-replacement zone lies under the intermediate zone and an approximately five meters thick feldsparquartz-muscovite-schorlite zone on the SE side of it. Between these zones and the country rock there is medium coarse feldspar-quartz pegmatite with aplitic varieties nearest the country rock (Fig. 1).
The exploitation of the Kaatiala pegmatite started in 1942 and terminated in 1968 owing to the exhaustion of the economically workable zones of the deposit. The total mining amounted to 136000 tons of country rock and 516000 tons of pegmatite of which 160000 tons of potash feldspar and 30000 tons of quartz was selected. In addition, 700 tons of muscovite mica, 5 tons of columbite, 5 tons of löllingite and 18 tons of beryl were produced. The Kaatiala pegmatite has been described earlier in some detail by i.a. Nieminen (1954), Neuvonen (1960) and Haapala (1966).

\section{The beryl specimens}

Although the occurrence of beryl in the Kaatiala pegmatite has been known for over a 


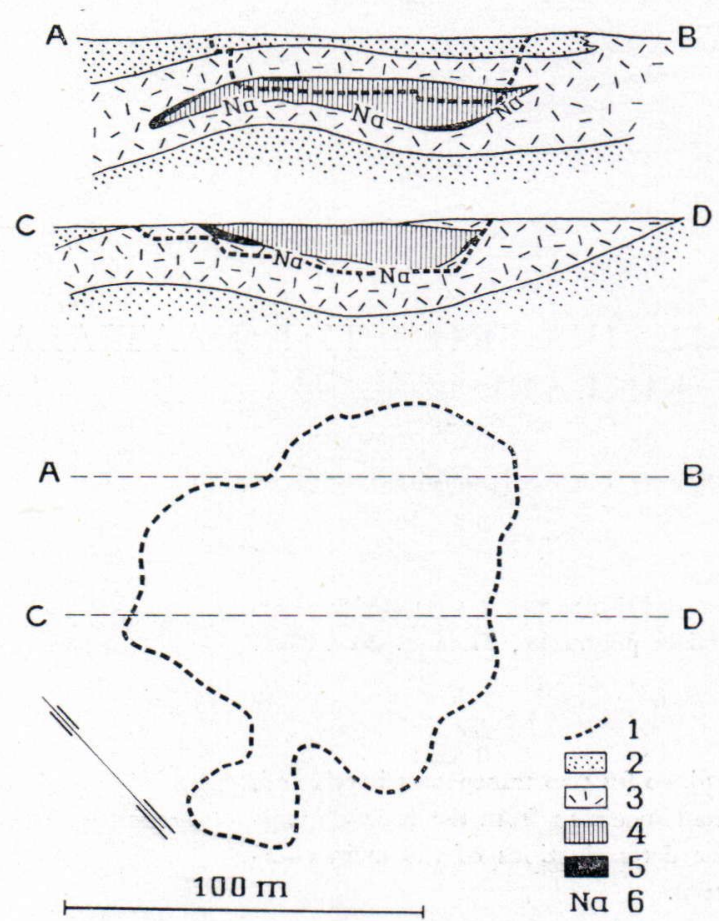

FIG. 1. The Kaatiala pegmatite according to Neuvonen (1960).

1. Quarry boundary. 2. Country rock. 3. Pegmatite. 4. Feldspar. 5. Quartz. 6. Na-Li zone.

hundred years (Holmberg, 1857), it was not found in significant amounts until 1951 when quarrying advanced through the intermediate zone and reached the underlying replacement zone.

Beryl occurs generally in the Kaatiala pegmatite as poorly-developed light green nontransparent crystals. As a very beautiful rarity a fully transparent honey-coloured specimen (K-188) was found in 1961 from the replacement zone in association with albite, muscovite and quartz. The specimen was a broken piece with the size of a fist and showing only two recognizable defective, grooved crystal surfaces.

In addition to this singlecoloured transparent specimen, about a dozen water-clear welldeveloped tabular beryl crystals (K-115) flat-

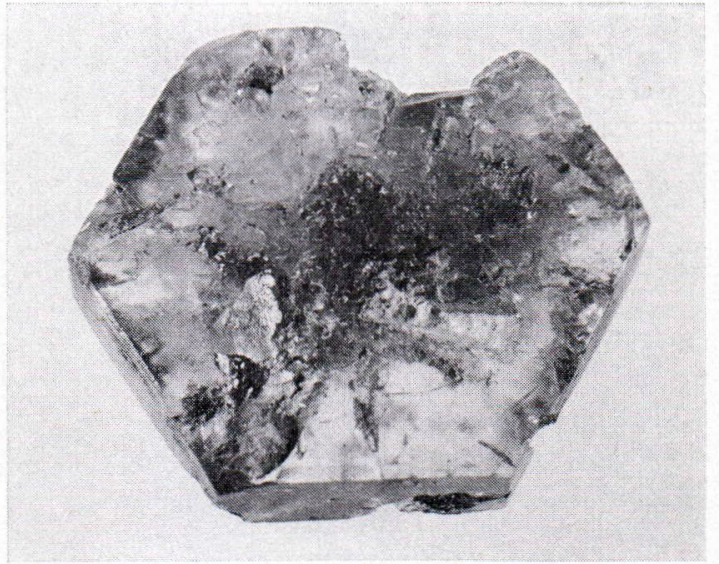

FIG. 2. The beryl specimen (K-115). Magn. 2X.

tened parallel to the basal planes (Fig. 2) were found in the kaolinized cavities of the replzcement zone. The cavities also contained coloured tourmaline and phlogopite.

Because of their rarity and special characteristics the two transparent beryl specimens were subjected to a chemical and mineralogical investigation together with one normal nontransparent beryl (K-177). The latter was a broken fragment of irregular cubic shape about $10 \times 10$ $\mathrm{cm}$ in size. It had only one diagonal crystal face covered with muscovite scales and was light green in colour.

\section{X-ray crystallography}

$\mathrm{X}$-ray powder diffraction patterns of the three beryls were recorded at $25^{\circ} \mathrm{C}$ on a Philips diffractometer using Ni-filtered $\mathrm{Cu} K \alpha$ radiation $(\lambda=$ $1.5418 \AA)$. Silicon ( $a=5.4310 \AA$ ) was used as internal standard. The unit cell dimensions were obtained by a least squares refinement of the singly indexed lines using a computer program written by Werner (1969). Results of the X-ray study and of the determination of the refractive indices are presented in Table 1. 
TABLE 1

Unit cell dimensions and refractive indices of the beryls from the Kaatiala pegmatite

\begin{tabular}{cc|c|c|c}
\hline & & $K-115$ & $K-188$ & $K-177$ \\
\cline { 2 - 4 } & & & \\
$a_{0}(\AA)$ & $\ldots$ & $9.224 \pm 0.003$ & $9.215 \pm 0.004$ & $9.216 \pm 0.003$ \\
$c_{0}(\AA)$ & $\ldots \ldots$ & $9.239 \pm 0.006$ & $9.205 \pm 0.007$ & $9.207 \pm 0.008$ \\
$\gamma$ & $\left({ }^{\circ}\right) \ldots \ldots$ & 120 & 120 & 120 \\
$\omega$ & $\ldots \ldots \ldots$ & 1.590 & 1.585 & 1.583 \\
$\varepsilon \ldots \ldots \ldots \ldots$ & 1.584 & 1.579 & 1.577
\end{tabular}

\section{Chemical composition}

Main components, alkalis and water

Aluminium, beryllium, silicon, lithium, sodium and potassium were determined by atomic absorption spectrometry using a Perkin-Elmer 303 spectrometer. The sample was dissolved in a mixture of fluoboric and boric acids according to the method of Bernas (1968). The method of addition was employed in the determinations.

Rubidium and caesium were determined by $\mathrm{X}$-ray fluorescence using a Philips semi-automatic X-ray spectrometer PW1220/00; the analytical lines used were $\mathrm{Rb} K \alpha$ and $\operatorname{Cs} K \alpha$.

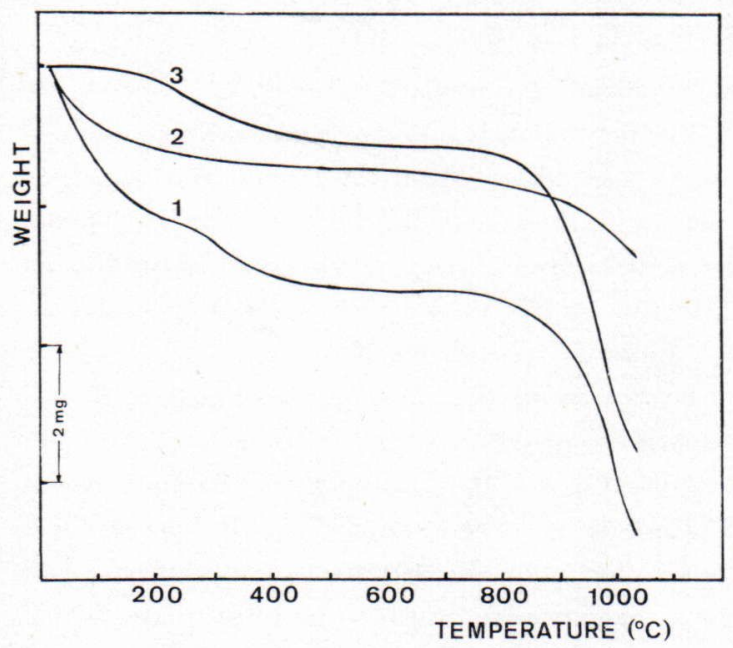

FIG. 3. Thermograms of the beryl specimens. Heating rate was $6^{\circ} \mathrm{C} / \mathrm{min}$. from $25^{\circ} \mathrm{C}$ to $1040^{\circ} \mathrm{C}$ and the sample weight was $261.5 \mathrm{mg}$. Numbers 1, 2 and 3 refer to beryls $\mathrm{K}-188, \mathrm{~K}-115$ and $\mathrm{K}-177$, respectively.
TABLE 2

The contents of beryllium, aluminium, silicon, alkalies and water.

\begin{tabular}{|c|c|c|c|}
\hline & $K-115$ & $K-188$ & $K-177$ \\
\hline $\mathrm{Al}_{2} \mathrm{O}_{3} \ldots \ldots \ldots$ & $16.90 \%$ & $18.40 \%$ & $18.50 \%$ \\
\hline $\mathrm{BeO} \ldots \ldots \ldots \ldots$ & 10.85 & 11.43 & 11.67 \\
\hline $\mathrm{SiO}_{2} \ldots \ldots \ldots \ldots$ & 63.40 & 64.70 & 64.00 \\
\hline $\mathrm{Li}_{2} \mathrm{O} \ldots$ & 1.02 & 0.65 & 0.60 \\
\hline $\mathrm{Na}_{2} \mathrm{O} \ldots \ldots \ldots$ & 0.92 & 1.22 & 2.30 \\
\hline $\mathrm{K}_{2} \mathrm{O} \ldots \ldots \ldots$ & 0.05 & 0.07 & 0.14 \\
\hline $\mathrm{Rb}_{2} \mathrm{O} \ldots \ldots \ldots$ & 0.01 & 0.02 & 0.02 \\
\hline $\mathrm{Cs}_{2} \mathrm{O} \ldots \ldots \ldots$ & 3.66 & 0.31 & 0.25 \\
\hline $\mathrm{H}_{2} \mathrm{O} \ldots \ldots \ldots \ldots$ & 2.30 & 2.68 & 2.34 \\
\hline Total $\ldots \ldots \ldots$ & $99.11 \%$ & $99.48 \%$ & $99.82 \%$ \\
\hline $\begin{array}{r}\text { The sum of } \\
\text { alkalies } \ldots\end{array}$ & $5.66 \%$ & $2.27 \%$ & $3.31 \%$ \\
\hline
\end{tabular}

Water was determined as the loss of weight in ignition at $1200^{\circ} \mathrm{C}$. Thermogravimetric and differential thermal analyses were performed in the Mettler Thermoanalyzer. The results (Fig. 3) indicate that although part of the water is lost at temperatures below $400^{\circ} \mathrm{C}$ a temperature of $1100-1200^{\circ} \mathrm{C}$ is needed to remove the final traces of water. Mass spectrometric analysis (cf. chapter on trace elements) was used to ascertain that no alkalis were lost when the sample was heated to $1200^{\circ} \mathrm{C}$.

The analytical results regarding the main components, alkalis and water, are presented in Table 2.

\section{Trace elements}

Trace elements were analyzed by a double focusing AEI mass spectrograph type 702 using $r f$ spark and photographic detection.

The electrodes were prepared by mixing 100 $\mathrm{mg}$ of powdered sample with an equal weight of graphite powder (Ringsdorff RW A) and compressing the mixture into a rod in a polyethene slug.

The mass spectra $\left({ }^{7} \mathrm{Li}-{ }^{238} \mathrm{U}\right)$ were recorded on Ilford Q 2 plates and the optical densities measured with an automatic recording microdensitomer (Joyce, Loebl \& Co.). Isotopes ${ }^{29} \mathrm{Si}$ and ${ }^{30} \mathrm{Si}$ were used as internal standards. 
The contents of the elements in the samples were calculated from

$$
C_{i}=C_{s} \frac{E_{s} I_{s} A_{i}}{E_{i} I_{i} R_{i} A_{s}}
$$

where $C_{i}$ is the content of element $i$ to be analyzed in ppm (weight)

$\mathrm{C}_{\mathrm{s}}$ is the content of the internal standard element in ppm (weight)

$E_{i}$ and $E_{s}$ are the exposures giving the line of the element to be analyzed and the internal standard, respectively, the same density

$I_{i}$ and $I_{s}$ are the isotopic abundances of the isotope of element $i$ and the internal standard isotope, respectively

$R_{i}$ is the relative sensitivity factor

$A_{i}$ and $A_{s}$ are the atomic weights of element $\mathrm{i}$ and the internal standard element, respectively

The mass spectographic data from photoplates were processed with programs written by Hiltunen (1970). The emulsion calibration

TABLE 3.

Results of the mass spectrographic analyses in ppms (weight).

\begin{tabular}{|c|c|c|c|}
\hline & $K-115$ & $K-188$ & $K-177$ \\
\hline $\mathrm{Mg} \ldots \ldots \ldots \ldots \ldots$ & 85 & 150 & 500 \\
\hline $\mathrm{Ca} \ldots \ldots \ldots \ldots$ & 100 & 250 & 170 \\
\hline $\mathrm{Sr} \ldots \ldots \ldots \ldots$ & 2 & - & - \\
\hline $\mathrm{Ba} \ldots \ldots \ldots \ldots$ & 1 & - & 一 \\
\hline $\mathrm{Sc} \ldots \ldots \ldots \ldots$ & 25 & 12 & 4 \\
\hline Ti $\ldots \ldots \ldots \ldots$ & 25 & 40 & 6 \\
\hline $\mathrm{V} \ldots \ldots \ldots \ldots$ & 1 & 一 & 2 \\
\hline $\mathrm{Cr} \ldots \ldots \ldots \ldots$ & 85 & 160 & - \\
\hline $\mathrm{Mn} \ldots \ldots \ldots \ldots \ldots$ & 50 & 160 & 30 \\
\hline $\mathrm{Fe} \ldots \ldots \ldots \ldots$ & 660 & 800 & 1800 \\
\hline $\mathrm{Ni} \ldots \ldots \ldots \ldots \ldots$ & 6 & - & 2 \\
\hline $\mathrm{Z}_{\mathrm{n}} \ldots \ldots \ldots \ldots$ & 11 & 180 & 100 \\
\hline B $\ldots \ldots \ldots \ldots \ldots$ & 1 & 9 & - \\
\hline $\mathrm{Ga} \ldots \ldots \ldots \ldots$ & 60 & 30 & 35 \\
\hline $\mathrm{T} 1 \ldots \ldots \ldots \ldots$ & 1 & - & - \\
\hline $\mathrm{Ge} \ldots \ldots \ldots \ldots$ & 2 & 3 & 1 \\
\hline Sn $\ldots \ldots \ldots \ldots$ & 45 & 2 & 2 \\
\hline $\mathrm{Pb} \ldots \ldots \ldots \ldots \ldots$ & 1 & 二 & - \\
\hline$P \ldots \ldots \ldots \ldots \ldots$ & 110 & 12 & 一 \\
\hline As $\ldots \ldots$. & 5 & 一 & - \\
\hline$F \ldots \ldots \ldots \ldots$ & - & 7 & - \\
\hline
\end{tabular}
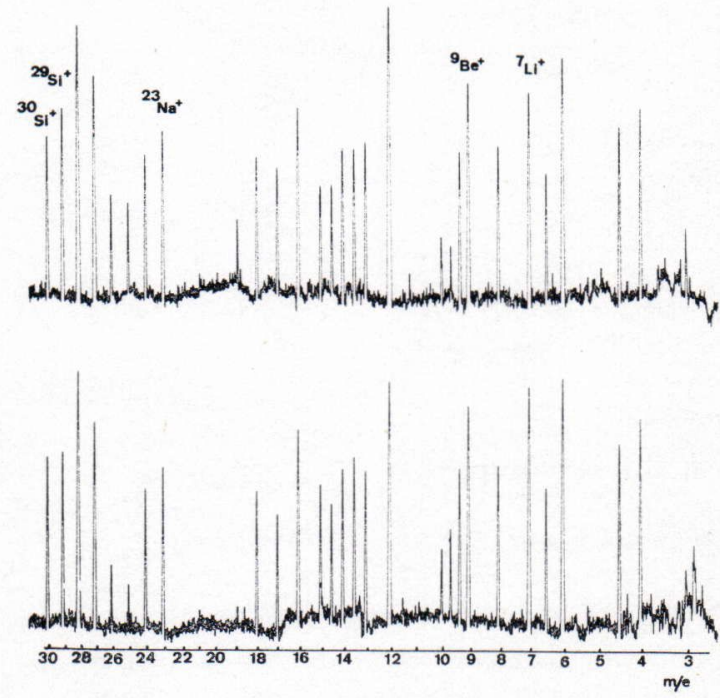

Frg. 4. Mass spectra of beryl K-188 obtained after heating to $1200^{\circ} \mathrm{C}$ (below) and before it (above).

function was obtained by a least squares fitting of a polynomial of third degree on the peak densities and $\log$ exposures of the internal standard lines. This function was used to obtain the ratio $E_{s} / E_{i}$ for each useful line and exposure of isotope »i». In this way $1-5$ different values for $C_{i}$ were obtained and the average value was calculated. For all elements the relative sensitivity factors were assumed to equal 1.

The results of the mass spectrographic analyses are presented in Table 3 . Concentrations less than $1 \mathrm{ppm}$ are indicated by a dash. Those elements whose concentration in all samples was found to be less than $1 \mathrm{ppm}$ are not included in the table.

The error in the mass spectrographic determinations using photoplate detection can be estimated as $\pm 30 \%$ at the most (Erämetsä and Yliruokanen, 1971). However, the errors are far smaller when the densities are obtained from the same exposure on the same photoplate. With this procedure it was possible to reduce the errors and to ensure that there were no changes in the alkali content of beryls after heat treatment (Fig. 4.). 


\section{Discussion}

The crystal structure of beryl has been well established (Gibbs, Breck and Meagher, 1968 and Morosin, 1972) as rather regular $\mathrm{Si}_{6} \mathrm{O}_{18}$ rings linked together by $\mathrm{Be}$ and $\mathrm{Al}$. This structure can accommodate other elements as shown by the chemical analysis. Without exception natural beryls contain alkalis and water. The alkali content can be quite high as shown by the caesium content of beryl K-115 in this study.

The alkali content affects the diffraction intensities and unit cell dimensions (Vorma, Sahama and Haapala, 1965 and Bakakin, Rylov and Belov, 1970) and the refractive indices (Beus, 1966a). As shown by Vorma et al. (1965) the alkalis and water, with the possible exception of lithium, are most probably situated in position $2 a$, i.e. in the channels between the $\mathrm{Si}_{6} \mathrm{O}_{18}$ rings. Our intensity measurements with beryl K-115 according to the method described by Vorma et al. (1965) support this finding. The measured intensity ratio of the $21 \overline{3} 2$ and $11 \overline{2} 2$ reflections $(0.77)$ is in agreement with the calculated ratio (0.73). Owing to its high alkali content, the same beryl (K-115) has a significantly longer $c$-axis $(9.239 \pm 0.006 \AA)$ than the other two. Also the refractive indices show a correlation with the alkali content ( $c f$. Tables 1 and 2 ). The high sodium content of beryl K-117 as compared to beryl $\mathrm{K}-188$ is possibly due to the alteration products, whose presence was confirmed by microscopic examination.

The water in the beryls is released at abnormally high temperature as seen from the thermogravimetric and mass spectrometric studies. Beryl K-115 in particular seems to hold water quite efficiently (Fig. 3). This might be due to the high content of the relatively large caesium ions which prevent the water from being released as suggested by Ginzburg (1955).

Concerning the trace elements, beryl K-115 has the highest contents of $\mathrm{Tl}, \mathrm{Sn}, \mathrm{Pb}, \mathrm{P}$ and $\mathrm{As}$ while beryl K-188 is the only specimen containing noticeable amounts of $\mathrm{B}$ and $\mathrm{F}$. The occurrence of these elements indicates final stage crystallization.

Beryls with a high lithium and caesium content are usually called vorobyevite or morganite (Beus, 1966b). However, since a generally accepted characteristic of morganite is its pink colour, the colourless specimen K-115 in this study could be called vorobyevite and the honey-coloured beryl specimen K-118 heliodor. The colour of the latter is probably due to the chromophore content ( $\mathrm{Fe}, \mathrm{Cr}, \mathrm{Mn}$ ) which is higher than in the colourless vorobyevite (cf. Table 3.).

Acknowledgement - The authors are indebted to Dr. Ilmari Haapala for his critical reading of the manuscript. 


\section{REFERENCES}

BaKakin, V. V., Rylov, G. M. and Belov, N. V. (1970) $\mathrm{X}$-ray diffraction data for identification of beryl isomorphs. Geochem. Int. 7, pp. 924-933.

Bernas, B. (1968) A new method for decomposition and comprehensive analysis of silicates by atomic absorption spectrometry. Anal. Chem. 40, pp. 1682-1686.

Beus, A. A. (1966a) Geochemistry of beryllium and genetic types of beryllium deposits. W. F. Freeman and Co., San Fransisco, p. 76.

Beus, A. A. (1966b) Ibid., pp. $83-84$.

Erämetsä, O. and Yliruokanen, I. (1971). The rare earths in lichens and mosses. Suomen Kemistilehti B 44, pp. 121-128.

Gibbs, G. V., Breck, D. W. and Meagher, E. P. (1968) Structural refinement of hydrous and anhydrous synthetic beryl, $\mathrm{Al}_{2}\left(\mathrm{Be}_{3} \mathrm{Si}_{6}\right) \mathrm{O}_{18}$. Lithos 1, pp. 275-285.

Ginzbur G, A. I. (1955) On the question of the composition of beryl. Trudy Mineralog. museum. Akad. Nauk. SSSR. 7, pp. $56-69$.

HaApala, I. (1966) On the granitic pegmatites in the Peräseinäjoki-Alavus area, South Pohjanmaa, Finland. Bull. Comm. géol. Finlande 224, pp. 89-90.
Hiltunen, L. (1970) Unpublished computer programs.

Holmber G, H. J. (1857) Mineralogische Wegweiser durch Finnland. Bidrag till Finlands Naturkännedom, Etnografi och Statistik. Första Häftet, pp. 3-76.

Morosin, B. (1972) Structure and thermal expansion of beryl. Acta Cryst. B 28, pp. 1899-1903.

Neuvonen, K. J. (1960) The pegmatite of Kaatiala, Int. Geol. Congress, XXI Session, Norden 1960. Nonmetallic mineral deposits, Finland., pp. 50-51.

Nieminen, K. (1954) The pegmatite quarries of Kaatiala. In The Mines and Quarries of Finland, edited by E. Aurola. Geotekn. julkaisuja 55, pp. 89-91.

Werner, P.-E. (1969) A Fortran program for leastsquares refinement of crystal-structure cell dimensions. Arkiv kemi 31, pp. 513-516.

Vorma, A., Sahama, Th.G. and Haapala, I. (1965) Alkali position in the beryl structure. C. R. Soc. geol. Finlande 37, pp. 119-129.

Manuscript received, October 23, 1972. 